\title{
LEGAL ASSISTANCE OF GOVERNMENT LAW OFFICE IN THE PROCUREMENT OF GOODS AND SERVICES
}

\author{
Susislo Susilo \\ Civil and State Administration Section, Kejaksaan Negeri Muaro Jambi
}

Muhamad Adji Rahardian Utama*

Faculty of Law, Universitas Negeri Semarang, Indonesia

Anita Carolina Rajagukguk

Faculty of Law, Universitas Negeri Semarang, Indonesia

*Email: adji.info@gmail.com

Procurement of goods/services is an activity to obtain goods/services by other Ministries/Institutions/Regional Work Units/Institutions whose process starts from planning needs to completion of all activities to obtain goods/services. The goods/service procurement activities are financed by the APBN/APBD, either carried out independently or by goods/service providers. The procurement of goods/services is essentially an attempt by the user to obtain or realize the goods/services it needs, by using certain methods and processes in order to reach an agreement on specifications, prices, time, and other agreements. The President of the Republic of Indonesia, in the process of dealing with the

The Indonesian Journal of International Clinical Legal Education DOI: https://doi.org/10.15294/ijicle.v3i3.48056

Submitted: Dec 12, 2020 Revised: May 23, 2021 Accepted: July 29, 2021 Available online at https://journal.unnes.ac.id/sju/index.php/iccle (C) 2021 Authors. This work is licensed under a Creative Commons AttributionShareAlike 4.0 International License (CC BY-SA 4.0). All writings published in this journal are personal views of the authors and do not represent the views of this journal and the author's affiliated institutions.

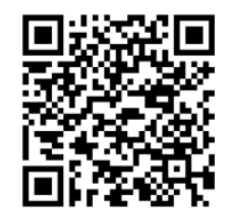


Susilo, et. al.

Covid-19 pandemic, has given instructions that were forwarded to the Deputy Attorney General for Civil and State Administration through circular number SE-02/G/Gs.2/04/2020 to carry out the stages quickly, precisely, focus integrated and synergistic among Ministries, institutions and local governments in the process of procuring goods and services. In the procurement process in an emergency, there are at least four important phases, namely planning, implementing, settling payments, and auditing. One of the duties and functions of the Junior Attorney General for Civil and State Administration is Legal Considerations consisting of Legal Opinion, Legal Assistance, and Legal Audit. Legal Assistance is a legal service provided by the State Attorney in the form of a legal opinion on an ongoing basis on an activity proposed by the Petitioner and ends with a conclusion on the provision of such Legal Opinion in the form of Legal Assistance Official Report.

Keywords: Procurement, Legal Assistance, State Attorney

\section{INTRODUCTION}

Procurement of goods/services is an activity to obtain goods/services by other Ministries/Institutions/Regional Work Units/Institutions whose process starts from planning needs to completion of all activities to obtain goods/services. The goods/service procurement activities are financed by the APBN/APBD, either carried out independently or by goods/service providers. The procurement of goods/services is essentially an attempt by the user to obtain or realize the goods/services it needs, by using certain methods and processes in order to reach an agreement on specifications, prices, time, and other agreements. ${ }^{1}$

Procurement of goods and services (procurement) needs to be programmed by the government or private institutions because of the need for a good or service. For example, office stationery (ATK) needed by an agency, medicine for the needs of health centers and hospitals, fuel for government-owned vehicles, war equipment for military agencies, construction for consulting services, and other service needs. In order for the purpose of the procurement of goods/services to be carried out as well as possible, both parties, namely the User and the Provider, must always adhere to the philosophy of the procurement of goods/services, comply

1 Ahmad Ahmad, Abd. Kadir Adys \& Nasrul Haq. "Implementasi E-Procurement Dalam Pengadaan Barang dan Jasa Di Bagian Layanan Pengadaan Barang dan Jasa Pemerintah (BLPBJ) Sekretariat Daerah Kota Makassar.” Journal Public Policy and Management 2(2), 2020, 85-86. 
Susilo, et.al.

with the ethics and norms of the procurement of goods/services in force, follow the principles, method and process of procuring standard goods and services. The procurement of these goods and services is bound by a contract between the government (Ministry/Institution/Regional Apparatus) as the User and the company (either state-owned or private) and even individuals as the Provider. ${ }^{2}$

The President of the Republic of Indonesia, in the process of dealing with the Covid-19 pandemic, has given instructions that were forwarded to the Deputy Attorney General for Civil and State Administration through circular number SE-02/G/Gs.2/04/2020 to carry out the stages quickly, precisely, focus integrated and synergistic among Ministries, institutions and local governments in the process of procuring goods and services. The President has instructed all Ministries/Agencies and regions to refocus the budget for health funds, social assistance or social assistance and support the business world, especially MSMEs. In addition, they also made budget cuts for fiscal consolidation, and there were also expenditures that could not be carried out in the Covid-19 condition. ${ }^{3}$ At present, there have also been several activities that have been refocused so that funds can be reallocated for the Covid-19 response program, such as official travel and other activities that cannot be carried out during the emergency period. From the results of the reallocation, the budget will be aimed at several Ministries/Institutions related to the technicalities of Covid-19 countermeasures, such as the Ministry of Health, the Ministry of Education and Culture, the Ministry of Defence, the Indonesian Police, the Ministry of Foreign Affairs, and other Ministries/Agencies Covid-19. ${ }^{4}$

In order to carry out support for the instructions from the President himself, it is necessary to take fast and precise steps in the process of providing legal opinions and legal assistance which is specialized in the procurement of goods and services related to medical devices and medical devices to deal with the Covid pandemic. -19. In the procurement process in an emergency, there are at least four important phases, namely planning, implementing, settling payments, and auditing. One of the duties and functions of the Junior Attorney General for Civil and State Administration is Legal Considerations consisting of Legal Opinion, Legal Assistance, and Legal Audit. Implementation of providing Legal Opinions, Legal Assistance, and Legal Audits has been

2 Ade Maman Suherman, Pengadaan Barang dan Jasa (Government Procurement) Perspektif Kompetisi, Kebijakan Ekonomi, dan Hukum Perdagangan Internasional (Jakarta: Publisher Rajawali Pers, 2018), p. 12-14.

3 Kantor Pengacara Negara, Pedoman Pendampingan Keperdataan Dalam Pengadaan Barang/Jasa (Jakarta: Publisher Kejaksaan Republik Indonesia, 2020), p. 8-10.

4 M. Husni Thamrin, Thesis: “Analisis Penggantian Perpres 54 Tahun 2010 ke Perpres 16 Tahun 2018 tentang Pengadaan Barang/Jasa Pemerintah di Lingkungan Sekretariat Daerah Kabupaten Muaro Jambi” (Jambi: Universitas Sulthan Thaha Saifuddin, 2019), p. 1-3. 
Susilo, et. al.

regulated in the Regulation of the Attorney General of the Republic of Indonesia Number PER-025/A/JA/11/2015 concerning Guidelines for Law Enforcement, Assistance Law, Legal Considerations, Other Legal Actions, and Legal Services in the Civil and Administrative Sector. Legal Assistance is a legal service provided by the State Attorney in the form of legal opinion on an ongoing basis on an activity proposed by the Petitioner and ends with a conclusion on the provision of such Legal Opinion in the form of Legal Assistance Official Report. ${ }^{5}$

This writing uses an empirical juridical approach. With this approach, this paper is focused on examining the legal assistance of the Prosecutor's Office in the process of procuring goods and services for the Muaro Jambi District Health Office during the pandemic through analysis of the Goods and Services Procurement Act, health law, interviews with resource persons existing data in the field and the media, and other related laws and regulations. In addition, this paper also analyzes the relationship between related laws with one another. Therefore, the data used in this paper is primary, namely data obtained from field observations and from books and data published by related institutions, especially the Muaro Jambi Regency Government, the Muaro Jambi District Health Office, and the Muaro Jambi District Prosecutor's Office. ${ }^{6}$

\section{PROCESS OF PROCUREMENT OF GOODS AND SERVICES AT THE HEALTH OFFICE OF MUARO JAMBI REGENCY DURING THE PANDEMIC PERIOD}

The term procurement specifically refers to an activity of providing goods and services to government institutions or agencies itself, the implementation of which is carried out based on the prevailing laws and regulations. For companies, the procurement of goods is an important activity in maintaining the survival of the company. ${ }^{7}$ According to

5 Regulation of the Attorney General of the Republic of Indonesia Number PER025/A/JA/11/2015 concerning Guidelines for the Implementation of Law Enforcement, Legal Aid, Legal Considerations, Other Legal Actions, and Legal Services in the Civil and State Administration.

6 Bambang Sunggono, Metodologi Penelitian Hukum (Jakarta: Publisher PT RajaGrafindo Persada, 2011), p. 47.

7 Rahmat Hidayat. "Penerapan e-Procurement Dalam Proses Pengadaan Barang Dan Jasa Pemerintah Guna Mendukung Ketahanan Tata Pemerintahan Daerah (Studi pada Unit Layanan Pengadaan Barang dan Jasa Pemerintah Kabupaten Penajam Paser Utara Provinsi Kalimantan Timur).” Journal Ketahanan Nasional 21.2 (2019): 223-225. 
Susilo, et.al.

Article 1 paragraph 1 of Presidential Regulation No. 54 Year 2010 as most recently amended by Presidential Regulation No. 70 Year 2012 concerning Government Procurement of Goods and Services, it is stated that, "Procurement of goods and services or procurement is an activity to obtain goods and services by the Ministry, Institution or Work Unit of the region or institution (K/L/SKPD/I) whose process starts from planning needs to be completed all activities to obtain goods and services." 8

The procurement process itself is the same as the process of buying or acquiring a company. The process of procuring goods and services itself starts from a purchase transaction or a sale of goods in the market directly or in cash, then progresses to a purchase where the payment period is due, by creating accountability documents for buyers and sellers, and finally through procurement through the auction process. itself. Procurement of goods began when there was a market where people could buy and sell goods. The method or method used in buying and selling goods is a way of directly bargaining between the buyer or user and the seller or provider of the goods. If in the bargaining process a price agreement has been reached, then it is followed by a sale and purchase transaction, in which the provider of goods hands over the goods to the user and the user pays based on the agreed price to the goods provider. The process of bargaining and buying and selling transactions is carried out directly without being supported by purchase documents or documents for payment and receipt of goods. ${ }^{9}$

The large number and types of items to be purchased, of course, will take a long time if bargaining is to be done. Usually the user himself will list the quantity and type of goods purchased in writing, which is then submitted to the supplier of goods so that they can bid in writing as well. The written list of goods shall itself constitute the origin of the purchase document, while the bid with the price made in writing constitutes the origin of the bid document itself. The procurement of goods itself by ordering turned out to be not limited to orders for movable goods, but also immovable goods such as houses, buildings, bridges, dams, and others. For ordering goods in the form of buildings, the user usually provides a plan drawing or technical drawing of the building being ordered. Ordering or procuring goods in the form of a building is the origin of the procurement of contract work which is then called the procurement of contracting services. Now the procurement of goods is not limited to tangible goods, but also intangible goods. Intangible goods

8 Article 1 Pasal 1 President Regulation No. 54 Year 2010 as amended most recently by Presidential Regulation No. 70 Year 2012 concerning Government Procurement of Goods and Services.

9 Arindra Rossita Arum Nurchana, Bambang Santoso Haryono \& Romula Adiono. "Efektivitas E-Procurement Dalam Pengadaan Barang/Jasa (Studi terhadap Penerapan E-Procurement dalam Pengadaan Barang/Jasa di Kabupaten Bojonegoro)." Journal Administrasi Publik 2.2 (2020):356-357. 
Susilo, et. al.

are generally services, for example, health services, educational services, consulting services, supervision services, management services, and others. The procurement of intangible goods, which are generally in the form of services, is the origin of the procurement of consulting services and other services. ${ }^{10}$

President Joko Widodo himself has issued a Government Regulation in Lieu of Law Number 1 of 2020 concerning State Financial Policy and Financial System Stability for Handling the Coronavirus disease pandemic. Some observers have criticized with various concerns that this Government Regulation in lieu of Law Number 1 of 2020 will be a tool for the authorities to avoid future legal problems after the end of the pandemic. ${ }^{11}$ Procurement of goods and services during an emergency has been regulated in such a way as in Presidential Regulation Number 16 of 2018 concerning Procurement of Government Goods and Services. The term "emergency" itself which is used in the Presidential Regulation for the procurement of goods and services uses the term "certain circumstances" in which the process of implementing the procurement of goods and services is carried out through direct appointment. Further technical regulations related to the Procurement of Goods and Services in an emergency are completed in the Regulation of the Head of the Government Goods and Services Procurement Policy Agency Number 13 of 2018.The difference with the usual process of procuring goods and services in normal conditions is that the direct appointment is relatively faster, no need to announce on the LPSE (Electronic Procurement Service) website, there is no need for a price evaluation process, and the executing officials are directly PA, KPA, and PPK, do not need to form a Procurement Working Group. PA, KPA, or PPK can directly identify needs, analyze availability, appoint providers, issue a Goods and Services Provider Appointment Letter (SPPBJ), issue a Work Order (SPMK), make and sign contracts, carry out work, and handover work. In the procurement process in an emergency, there are at least four important phases, namely planning, implementing, settling payments, and auditing. ${ }^{12}$ According to the Head of LKPP Regulation No. 13 of 2018, ministers, heads of institutions or regional heads assign internal supervisors (BPKP, Government Internal Supervisory Apparatus or Independent Auditors) to conduct audits. Of the 4 phases, the most likely problem is during the audit. ${ }^{13}$

10 Adrian Sutedi, Aspek Hukum Pengadaan Barang \& Jasa dan Berbagai Permasalahannya, Edisi Kedua (Jakarta: Publisher Sinar Grafika, 2012), p. 73-75.

11 Merry Tjoanda. "Kekuatan Mengikat Surat Penunjukan Penyedia Barang dan Jasa Pemerintah dalam Kontrak Pengadaan Barang/Jasa Pemerintah di Masa Pandemi Covid-19" Journal SASI 26.3 (2020):406-407.

12 S. Ramli, Bacaan Wajib Sertifikasi Ahli Pengadaan Barang/Jasa dan Berbagai Permasalahannya (Jakarta: Publisher Sinar Grafika, 2014), p. 61-62.

13 Head of LKPP Regulation No. 13 Year 2018 concerning the Procurement of Goods and Services. 
Based on the results of the presentation of Covid-19 handling activities by the Health Office of Muaro Jambi Regency in 2020 which is based on the law to Presidential Instruction Number 4 of 2020 concerning Refocussing Activities, Budget Reallocation and Procurement of Goods and Services in the context of Accelerating Handling of Corona Virus Diseas2019 (Covid 19), Kep. . Minister of Health No. HK.01.07/MENKES/215/2020 Concerning Utilization of DAK in the Health Sector for handling Covid-19, PMK Number 19/PMK.07/2020 concerning Distribution and Use of Profit Sharing Funds, General Allocation Funds, and Regional Incentive Funds in 2020 Covid-19, Decree of the Regent of Muaro Jambi Number 236 of 2020 concerning the Determination of the Status of Emergency Preparedness for Non-Natural Disasters due to Corona Virus Desease 2019 (Covid 19) which explains the details of the funds for the refocussing conditions of the Muaro Jambi District Health Office budget, including DID funding sources of Rp. 21,917,117,000,-, DAK Fund for Disease Control Assignment of Rp. 531,750,000,-, Referral DAK Fund of Rp. 653,861,072,-, BTT Fund of Rp. 4,516,500,000,-, Non-Physical DAK Fund (BOK) of Rp. 10,990,922,300,-, and the DBH-CHT Fund of Rp. $69,050,930,-$. From the data itself, the realization of DID funds as of June 10, 2020 amounted to Rp. 1,796,679,900,- with a ceiling of $\mathrm{Rp}$. $21,917,117,000,-$, the realization of DAK funds for the assignment of disease control did not exist with a budget ceiling of Rp. 531,750,000,-, Realization of unexpected expenses (BTT) amounting to Rp. 3,701,995,500,- with a budget ceiling of Rp. 4,516,500,000, - Realization of referral DAK Funds does not exist with a budget ceiling of Rp. $653,861,072,-$, Realization of Non-Physical DAK Funds (BOK) does not exist with a budget ceiling of Rp. 10,990,922,300,-, Realization of DBHCHT funds does not exist with a budget ceiling of Rp. 69,050,930,-. ${ }^{14}$

\section{III.LEGAL ASSISTANCE OF GOVERNMENT LAW OFFICE IN PROCESS OF PROCUREMENT OF GOODS AND SERVICES AT THE HEALTH OFFICE OF MUARO JAMBI REGENCY DURING THE PANDEMIC PERIOD}

The President of the Republic of Indonesia, in the process of dealing with the Covid-19 pandemic, has given instructions that were forwarded to the Deputy Attorney General for Civil and State Administration through

14 Report on the Explanation of Covid-19 Handling Activities at the Muaro Jambi District Health Office in 2020. 
Susilo, et. al.

circular number SE-02/G/Gs.2/04/2020 to carry out the stages quickly, precisely, focus integrated and synergistic among Ministries, institutions and local governments in the process of procuring goods and services. The President has instructed all Ministries/Agencies and regions to refocus the budget for health funds, social assistance or social assistance and support the business world, especially MSMEs. In addition, they also made budget cuts for fiscal consolidation, and there were also expenditures that could not be carried out in the Covid-19 condition. ${ }^{15}$ Currently there have been several activities that have been focused so that funds can be reallocated for the Covid-19 response program, such as official trips and other activities that cannot be carried out during the emergency period. From the results of the reallocation, the budget will be aimed at several Ministries/Agencies related to Covid-19 countermeasures, such as the Ministry of Health, Ministry of Education and Culture, Ministry of Defense, Police of the Republic of Indonesia, Ministry of Foreign Affairs, and other Ministries/Agencies for equipment related to Covid-19 countermeasures. In order to carry out support for the instructions from the President himself, it is necessary to take quick and precise steps in the process of providing legal opinions and legal assistance that is specialized in the procurement of goods and services related to medical devices and medical devices to deal with the pandemic Covid-19. In the procurement process in an emergency, there are at least four important phases, namely planning, implementing, settling payments, and auditing. ${ }^{16}$

The Attorney General's Office of the Republic of Indonesia is a state institution that exercises state power, especially in the field of prosecution as regulated in Law No. 16 of 2004 concerning the Republic of Indonesia Attorney General's Office. Andi Hamzah said that prosecution was only carried out by the public prosecutor in accordance with his/her authority. Apart from criminal justice, the prosecutor's office also has a role in law, civil and state administration, namely representing the state and government in civil cases and state administration. Article 30 paragraph (2) of the Law on the Prosecution provides that "In the civil and state administration sector, the prosecutor with special powers can act both inside and outside the court for and on behalf of the state or government". ${ }^{17}$

The implementation of their duties and functions as state attorney in civil suitcases has been handled by the State Attorney Prosecutor representing various departments, governors, regents, state institutions, and BUMN. In fact, the President of the Republic of Indonesia has been

15 A. Listiyanto. "Pembaharuan Regulasi Pengadaan Barang dan Jasa Pemerintah." Journal Rechtsvinding 1.1 (2018):113-134.

16 Ibid.

17 Article 30 paragraph (2) of Law No. 16 Year 2004 concerning Special Prosecutors in the Civil and Administrative Sector. 
a "client" of the State Attorney General's Office several times by giving SKK (Special Power of Attorney) to the Prosecutor's Office in the function of State Attorney to represent him in court, which is generally won by the State Attorney General. The existence of this state attorney attorney has not been fully utilized by government agencies, StateOwned Enterprises (BUMN), Regional-Owned Enterprises (BUMD) to defend their interests in civil cases and state administration. The use of state attorney attorneys in practice is only a discourse for government agencies, State-Owned Enterprises (BUMN), Regional-Owned Enterprises (BUMD). The assignment of State Attorneys to Law is not only to safeguard state assets, but also to maintain the authority of the government and government officials. ${ }^{18}$

Based on the duties and powers of the prosecutor, the objectives of the state attorney serve as guidelines in carrying out the duties and functions of the Deputy Attorney General for Civil and State Administration (JAM DATUN) including, Preventing legal disputes in society, Preventing Government Authority, Saving State Wealth and Protecting Interests General. The term state attorney is not explicitly stated in the Law on the Prosecution, but the meaning of "special power" in the civil sector is automatically identical to "lawyer". ${ }^{19}$

If one examines the legal basis for the duties of the State Attorney's Office in the civil sector, it has existed since 1922, namely based on the provisions set out in Staatblad Number 522 of 1922 and until now its existence has never been revoked. With the birth of Law Number 5 of 1991, the duties of the Attorney General's Office in the civil sector were more solidified, even added to the duties in the field of state administration in connection with the enactment of Law Number 5 of 1986. The duties in the civil and state administration sector itself were subsequently carried out with based on KEPPRES Number 55 of 1991 concerning Duties and Authorities of the Attorney General's Office in Civil and State Administration, KEPJA Number KEP 035/JA/3.1992 concerning the organizational structure of the Attorney General's Office of the Republic of Indonesia, other KEPJA, INSJA, and JAM DATUN instructions. ${ }^{20}$

One of the duties and functions of the Junior Attorney General for Civil and State Administration is Legal Considerations consisting of Legal Opinion, Legal Assistance, and Legal Audit. Implementation of providing Legal Opinions, Legal Assistance, and Legal Audits has been

18 Bambang Hartono. "Analisis Terhadap Tugas dan Fungsi Jaksa Sebagai Pengacara Negara dalam Perkara Perdata." Journal Keadilan Progresif 3.2 (2019):47-49.

19 Regulation of the Attorney General of the Republic of Indonesia Number 006/A/JA/ 07/2017 concerning the Organization and Work Procedures of the Republic of Indonesia Public Prosecutors' Office.

20 Juristoffel Simanjuntak. "Kajian Yuridis Pemberian Bantuan Hukum Jaksa Pengacara Negara Dalam Perkata Perdata dan Tata Usaha Negara (TUN)." Journal Lex Administratum 6.1 (2018):154-155. 
Susilo, et. al.

regulated in the Regulation of the Attorney General of the Republic of Indonesia Number PER-025/A/JA/11/2015 concerning Guidelines for Law Enforcement, Assistance Law, Legal Considerations, Other Legal Actions, and Legal Services in the Civil and Administrative Sector itself. ${ }^{21}$ Legal Assistance is a legal service provided by the State Attorney in the form of legal opinion on an ongoing basis on an activity proposed by the Petitioner and ends with a conclusion on the provision of such Legal Opinion in the form of Legal Assistance Official Report. ${ }^{22}$

The stages of the implementation of the provision of legal assistance itself, namely starting with legal assistance which is carried out within the scope of both Civil and State Administration. The position of the State Attorney Attorney is to act as a legal advisor who does not have the authorization or authority to decide on an action and is not included in the work organization. State Attorneys only carry out legal assistance in normative juridical manner, without conducting technical project and financial analysis. State Attorney Prosecutors cannot be held accountable for the material actions taken by the Petitioners. State Attorneys to actively provide written Legal Opinions whether requested by the Petitioner, gradually or incidentally, relating to legal issues that arise during the Legal Assistance process. State attorney attorneys provide an incidental legal opinion which is conveyed orally as a legal advisor and must be followed up in writing in the form of a legal opinion. Legal assistance is carried out in stages from the beginning to the end of an activity or legal assistance is carried out partially for a stage of activity. The State Attorney General conducts an analysis of the alignment of a series of Legal Opinions that have been submitted as a single conclusion in the form of a final legal assistance report. ${ }^{23}$

In the process of legal assistance or Legal Assistance, the State Attorney General's Office of Muaro Jambi to the Muaro Jambi District Health Office in the context of procuring goods and services or Procurement of medical devices during the pandemic, the Muaro Jambi District Health Office asked for legal assistance or legal assistance at the same stage. where budget refocussing has been carried out and the goods are procured and distributed by parties who are trusted in their fields. Here the State Attorney General provides assistance when the distribution and procurement of goods takes place and supervises when there are items that do not fit the budget. Regarding this, the State Attorney General is only in the form of giving a legal opinion when something is wrong with the process of procuring goods and services or the procurement. Here, too, means that the strength of the legal opinion

21 Ibid.

22 RM. Surachman \& Andi Hamzah, Jaksa di Berbagai Negara, Peranan dan Kedudukannya (Jakarta: Publisher Sinar Grafika, 1995), p. 41.

23 Marwan Effendy, Kejaksaan Republik Indonesia, Posisi dan Fungsinya dari Perspektif Hukum (Jakarta: Publisher PT. Gramedia Pustaka Utama, 2005), p. 136. 
of the State Attorney General is not binding because it may or may not be accepted by the Muaro Jambi District Health Office. This is where it can be highlighted that there are indeed weaknesses in legal assistance from State Attorneys. However, during this pandemic, the need for agencies or institutions related to legal assistance, especially legal assistance, has increased considerably due to the urgency of the need for goods and services that need to be provided, where these needs and services are categorized as refocusing the budget for sudden goods and services which are not yet existed in previous years.

\section{CONCLUSION}

Legal arrangements regarding State Attorneys in the judicial system are contained in the laws and regulations governing the existence of prosecutors as state lawyers, namely Law Number 16 of 2004 concerning Attorney General's Office of the Republic of Indonesia Article 30 paragraph (2), Presidential Regulation Number 38 of 2010 concerning the Organizational Structure and Work Procedure of the Public Prosecutor's Office of the Republic of Indonesia Article 24 paragraph (2), and Regulation of the Attorney General of the Republic of Indonesia Number 040/A/JA/12/2010 concerning Standard Operating Procedure (SOP) for Implementation of Duties, Functions and Authorities of Civil and State Administration. The position or existence of the State Attorney's Office in handling disputes in the Civil and State Administration sector according to Law No. 16 of 2004 concerning the Attorney General's Office of the Republic of Indonesia, where the Attorney as State Lawyer can act in the Civil and State Administration to represent on behalf of State institutions, central or regional government agencies, State-Owned Enterprises (BUMN) or Regional-Owned Enterprises (BUMD). In the settlement of Civil and State Administrative disputes carried out by the State Attorney General is a form of legal assistance provided by the State Attorney's Office itself. The process of dispute resolution or state administration cases carried out by state attorneys here is based on a special power of attorney, which basically means that disputes are resolved either through litigation or by nonlitigation or out of court settlement.

\section{SUGGESTION}

It is hoped that with the existence of Law Number 16 of 2004 concerning the Republic of Indonesia Public Prosecutor's Office and various other laws and regulations, there is a need for socialization in order to establish good relations in carrying out functions as enforcers of justice, because 
Susilo, et. al.

many ordinary people know that prosecutors act only within the scope of the crime. only. The role of prosecutors as state lawyers in handling civil and state administrative disputes should be utilized properly by state institutions or agencies, central or regional government agencies, stateowned enterprises (BUMN) or regional-owned enterprises (BUMD) and the community, so that the existence of prosecutors as state lawyers is increasing.

\section{REFERENCES}

Ahmad, A. A., Kadir, A., \& Haq, N. (2020). Implementasi EProcurement Dalam Pengadaan Barang dan Jasa Di Bagian Layanan Pengadaan Barang dan Jasa Pemerintah (BLPBJ) Sekretariat Daerah Kota Makassar. Journal Public Policy and Management, 2(2), 85-86.

Effendy, M. (2005). Kejaksaan Republik Indonesia, Posisi dan Fungsinya dari Perspektif Hukum. Jakarta: PT. Gramedia Pustaka Utama.

Hartono, B. (2019). Analisis Terhadap Tugas dan Fungsi Jaksa Sebagai Pengacara Negara dalam Perkara Perdata. Journal Keadilan Progresif, 3(2), 47-49.

Hidayat, R. (2019). Penerapan e-Procurement Dalam Proses Pengadaan Barang Dan Jasa Pemerintah Guna Mendukung Ketahanan Tata Pemerintahan Daerah (Studi pada Unit Layanan Pengadaan Barang dan Jasa Pemerintah Kabupaten Penajam Paser Utara Provinsi Kalimantan Timur). Jurnal Ketahanan Nasional, 21(2), 223-225.

Jusuf, M. (2014). Hukum Kejaksaan Eksistensi Kejaksaan Sebagai Pengacara Negara dalam Perkara Perdata dan Tata Usaha Negara. Yogyakarta: PLaskBang Justitia.

Kantor Pengacara Negara. (2020). Pedoman Pendampingan Keperdataan Dalam Pengadaan Barang/Jasa. Jakarta: Penerbit Kejaksaan Republik Indonesia.

Listiyanto, A. (2018). Pembaharuan Regulasi Pengadaan Barang dan Jasa Pemerintah. Journal Rechtsvinding, 1(1), 113-134.

Nurchana, A. R. A, Haryono, B. S., \& Adiono, R. (2020). Efektivitas EProcurement Dalam Pengadaan Barang/Jasa (Studi terhadap Penerapan E-Procurement dalam Pengadaan Barang/Jasa di Kabupaten Bojonegoro). Journal Administrasi Publik, 2(2), 356357.

Ramli, S. (2014). Bacaan Wajib Sertifikasi Ahli Pengadaan Barang/Jasa dan Berbagai Permasalahannya. Jakarta: Sinar Grafika. 
Simanjuntak, J. (2018). Kajian Yuridis Pemberian Bantuan Hukum Jaksa Pengacara Negara Dalam Perkata Perdata dan Tata Usaha Negara (TUN). Journal Lex Administratum, 6(1), 154-155.

Suherman, A. M. (2018). Pengadaan Barang dan Jasa (Government Procurement) Perspektif Kompetisi, Kebijakan Ekonomi, dan Hukum Perdagangan Internasional. Jakarta: Rajawali Pers.

Sunggono, B. (2011). Metodologi Penelitian Hukum. Jakarta: PT RajaGrafindo Persada.

Surachman, R. M., \& Hamzah, A. (1995). Jaksa di Berbagai Negara, Peranan dan Kedudukannya. Jakarta: Sinar Grafika.

Sutedi, A. (2012). Aspek Hukum Pengadaan Barang \& Jasa dan Berbagai Permasalahannya, Edisi Kedua. Jakarta: Sinar Grafika.

Thamrin, M. H. (2019). “Analisis Penggantian Perpres 54 Tahun 2010 ke Perpres 16 Tahun 2018 tentang Pengadaan Barang/Jasa Pemerintah di Lingkungan Sekretariat Daerah Kabupaten Muaro Jambi". Thesis. Universitas Sulthan Thaha Saifuddin, Jambi.

Tjoanda, M. (2020). Kekuatan Mengikat Surat Penunjukan Penyedia Barang dan Jasa Pemerintah dalam Kontrak Pengadaan Barang/Jasa Pemerintah di Masa Pandemi Covid-19. Journal SASI, 26(1), 406-407.

\section{Laws and Regulations}

Article 1 paragraph 1 Presidential Regulation No. 54 Year 2010 as most recently amended by Presidential Regulation No. 70 Year 2012 concerning Government Procurement of Goods and Services.

Article 30 paragraph (2) of Law No. 16 Year 2004 concerning Special Prosecutors in the Civil and Administrative Sector.

Head of LKPP Regulation No. 13 Year 2018 concerning the Procurement of Goods and Services.

Regulation of the Attorney General of the Republic of Indonesia Number 006/A/JA/07/2017 concerning the Organization and Work Procedure of the Republic of Indonesia Attorney General's Office.

Regulation of the Attorney General of the Republic of Indonesia Number PER- 025/A/JA/11/2015 concerning Guidelines for Law Enforcement, Legal Aid, Legal Considerations, Other Legal Actions, and Legal Services in the Civil and State Administration.

\section{Other}

Report on the Explanation of Covid-19 Handling Activities at the Muaro Jambi District Health Office in 2020. 
Susilo, et. al.

\section{Conflicting Interest Statement}

All authors declared that there is no potential conflict of interest on publishing this article.

\section{Funding}

None

\section{Publishing Ethical and Originality Statement}

All authors declared that this work is original and has never been published in any form and in any media, nor is it under consideration for publication in any journal, and all sources cited in this work refer to the basic standards of scientific citation.

Cite this article as:

Susilo, S., Utama, M. A. R., \& Rajagukguk, A. C. (2021). Legal Assistance of Government Law Office in the Procurement of Goods and Services. The Indonesian Journal of International Clinical Legal Education, 3(3), 339-352. https://doi.org/10.15294/ijicle.v3i3.48056 